\title{
Article \\ "They Remembered That They Had Seen It in a Jewish Midrash": How a Samaritan Tale Became a Legend of the Jews
}

\author{
Steven Fine
}

Citation: Fine, Steven. 2021. “They Remembered That They Had Seen It in a Jewish Midrash": How a Samaritan Tale Became a Legend of the Jews. Religions 12: 635. https://doi.org/10.3390/rel12080635

Academic Editor: Reinhard Pummer

Received: 20 May 2021

Accepted: 29 June 2021

Published: 11 August 2021

Publisher's Note: MDPI stays neutral with regard to jurisdictional claims in published maps and institutional affiliations.

Copyright: (C) 2021 by the author. Licensee MDPI, Basel, Switzerland. This article is an open access article distributed under the terms and conditions of the Creative Commons Attribution (CC BY) license (https:// creativecommons.org/licenses/by/ $4.0 /)$.
Bernard Revel Graduate School of Jewish Studies, Yeshiva University, New York, NY 10463, USA; steven.fine@yu.edu

\begin{abstract}
This article relates the transmission history of a single Samaritan text and its fascinating trajectory from a Samaritan legend into early modern rabbinic tradition, and on to nineteenth and early twentieth century Jewish studies circles. It focuses on the only Samaritan narrative cited in all of Louis Ginzberg's monumental Legends of the Jews (1909-1938). Often called the "Epistle of Joshua son of Nun," I trace the trajectory of this story from a medieval Samaritan chronicle to Samuel Sulam's 1566 publication of Abraham Zacuto's Sefer Yuhasin. From there, we move to early modern belles lettres in Hebrew and Yiddish, western scholarship and then to the great Jewish anthologizers of the fin de siècle, Micha Yosef Berdyczewski, Judah David Eisenstein and Louis Ginzberg. I will suggest reasons why this tale was so appealing to Sulam, a Sephardi scholar based in Istanbul, that he appended it to Sefer Yuhasin, and what about this tale of heroism ingratiated it to early modern European and then early Zionist readers. The afterlife of this tale is a rare instance of Samaritan influence upon classical Jewish literature, undermining assumptions of unidirectional Jewish influence upon the minority Samaritan culture from antiquity to modern times.
\end{abstract}

Keywords: Samaritan; midrash; Aggada; Sefer Yuhasin; Joshua

This article relates the remarkable transmission history of a single Samaritan text and its fascinating trajectory from a Samaritan legend into early modern rabbinic tradition, and on to nineteenth and early twentieth century Jewish studies circles. It focuses on the only Samaritan narrative cited in all of Louis Ginzberg's (1909-1938) monumental Legends of the Jews. Often called the "Epistle of Joshua son of Nun", I will trace the trajectory of this story from a medieval Samaritan chronicle to Samuel Sulam's 1566 publication of Abraham Zacuto's Sefer Yuhasin. ${ }^{1}$ From there, we move to early modern belles lettres in Hebrew and Yiddish, western scholarship and then to the great Jewish anthologizers of the fin de siècle, Micha Yosef Berdyczewski, Judah David Eisenstein and Louis Ginzberg. This article suggests reasons why this tale was so appealing to Sulam, a Sephardi scholar based in Istanbul, that he appended it to Sefer Yuhasin, and what about this tale of heroism ingratiated it to early modern European and then early Zionist readers. I then contextualize the reticence of Ginzberg - and with him almost all midrash scholars after him $^{2}-$ to engage Samaritan sources, interpreting it with a mix of traditionalist and orientalist bias, in addition to an Emancipation yearning for acceptance in the overwhelming Protestant American academy of his day. The afterlife of "The Epistle of Joshua son of Nun" is the rare instance where Samaritan influence upon classical Jewish literature is documented, undermining the usual assumption of unidirectional Jewish influence upon the minority Samaritan culture from antiquity to modern times.

\section{Ginzberg's "War with the Armenians"}

Samaritan sources are explicitly mentioned three times in Ginzberg's Legends of the Jews. The first two are textual variants from the Samaritan Pentateuch in the copious notes. The third, however, is a Samaritan source embedded within the body of his narrative, which Ginzberg entitled "The War with the Armenians". This source is set at the highpoint of his saga of Joshua son of Nun. The story, as told by Ginzberg (and translated 
from German by Paul Radin and published in 1928), reads as follows (Ginzberg 1909-1938, 4:13-14):

Joshua's victorious course did not end with the conquest of the land. His war with the Armenians, after Palestine was subdued, marked the climax of his heroic deeds. Among the thirty-one kings whom Joshua had slain, there was one whose son, Shobach by name, was king of Armenia. With the purpose of waging war with Joshua, he united the forty five kings of Persia and Media, and they were joined by the renowned hero Japheth. The allied kings in a letter informed Joshua of their design against him as follows: "The noble, distinguished council of the kings of Persia and Media to Joshua, peace! Thou wolf of the desert, we well know what thou didst to our kinsmen. Thou didst destroy our palaces; without pity thou didst slay young and old; our fathers thou didst mow down with the sword; and their cities thou didst turn into a desert. Know, then, that in the space of thirty days, we shall come to thee, we, the forty-five kings, each having sixty thousand warriors under him, all of them armed with bows and arrows, girt about with swords, all of us skilled in the ways of war, and with us the hero Japheth. Prepare now for the combat, and say not afterward that we took thee at unawares".

The messenger bearing the letter arrived on the day before the Feast of Weeks. Although Joshua was greatly wrought up by the contents of the letter, he kept his counsel until after the feast, in order not to disturb the rejoicing of the people. Then, at the conclusion of the feast, he told the people of the message that had reached him, so terrifying that even he, the veteran warrior, trembled at the heralded approach of the enemy. Nevertheless, Joshua determined to accept the challenge. From the first words his reply was framed to show the heathen how little their fear possessed him whose trust was set in God. The introduction to his epistle reads as follows: "In the Name of the Lord, the God of Israel, who saps the strength of the iniquitous warrior, and slays the rebellious sinner. He breaks up the assemblies of marauding transgressors, and He gathers together in council the pious and the just scattered abroad, He the God of all gods, the Lord of all lords, the God of Abraham, Isaac, and Jacob. God is the Lord of war! From me, Joshua, the servant of God, and from the holy and chosen congregation to the impious nations, who pay worship to images, and prostrate themselves before idols: No peace unto you, saith my God! Know that ye acted foolishly to awaken the slumbering lion, to rouse up the lion's whelp, to excite his wrath. I am ready to pay you your recompense. Be ye prepared to meet me, for within a week I shall be with you to slay your warriors to a man". Joshua goes on to recite all the wonders God had done for Israel, who need fear no power on earth; and he ends his missive with the words: "If the hero Japheth is with you, we have in the midst of us the Hero of all heroes, the Highest above all the high". The heathen were not a little alarmed at the tone of Joshua's letter. Their terror grew when the messenger told of the exemplary discipline maintained in the Israelitish army, of the gigantic stature of Joshua, who stood five ells high, of his royal apparel, of his crown graven with the Name of God. At the end of seven days Joshua appeared with twelve thousand troops. When the mother of King Shobach who was a powerful witch, espied the host, she exercised her magic art, and enclosed the Israelitish army in seven walls. Joshua thereupon sent forth a carrier pigeon to communicate his plight to Nabiah, the king of the trans-Jordanic tribes. He urged him to hasten to his help and bring the priest Phinehas and the sacred trumpets with him. Nabiah did not tarry. Before the relief detachment arrived, his mother reported to Shobach that she beheld a star arise out of the East against which her machinations were vain. Shobach threw his mother from the wall, and he himself was soon afterward killed by Nabiah. Meantime Phinehas 
arrived, and, at the sound of his trumpets, the walls toppled down. A pitched battle ensued, and the heathen were annihilated.

In his scholarly note, published in volume six in the same year, Ginzberg references the source of this legend: ${ }^{3}$

Shulam in his appendix to his edition of Zacuto's Yuhasin, following a Samaritan chronicle (=Chronicon Samaritanum, ed. Juynboll, XXVI-XXXII); see also Yalkut Reubeni, Debarim (end), which follows Shulam ....

Ginzberg's mention of Dutch orientalist Theodor Willem Jan Juynboll's (1848) edition of the Samaritan Book of Joshua is significant. ${ }^{4}$ This text generated much interest among scholars of his day-particularly in Hebrew. A Hebrew translation of Juynboll's text by Raphael Kirchheim in his magnificent Hebrew introduction to Samaritanism, Karmei Shomron brought this text to the attention of Jewish readers in 1851 and Oliver Crane's (1890) English translation of the Samaritan Chronicle of Joshua did similarly in the Anglophone world. Hebrew versions acquired directly from Samaritans were published by Abraham Moses Luncz (1902) and Moses Gaster (1908a, with German translation). These texts occasioned some excitement. Columbia professor Richard Gottheil (the first Jewish scholar to hold a chair in "Rabbinical literature and the Semitic Languages" at a secular university, in 1887, and an elder colleague of Ginzberg), ${ }^{5}$ collaborating with M. Seligman, summarized the state of knowledge in The Jewish Encyclopedia (1901-1906). ${ }^{6}$

Sulam reproduced our tale on the last two pages of a history of the rabbis from antiquity to the expulsion from Portugal by Abraham Zacuto, an exile from Spain (1492) and Portugal (1497), who died around 1515. Sefer Yuhasin, The Book of Lineage, was published in Istanbul in 1566. This pious history of rabbinic culture and assertion of authority provided a shared narrative for a now "virtual" community. It was read by the literate elite of the now broadly stretched and traumatized Sephardic diaspora/"exile" in their mission to "restore the traditions marking their former lives in Iberia". ${ }^{7}$ Samuel Sulam was a Sephardi doctor, rabbinic intellectual and autodidact. ${ }^{8}$ He framed Sefer Yuhasin with his own introduction, added glosses throughout the work, upgraded the Hebrew and appended an anthology of additional literature at the end - the last of which is our Samaritan story. ${ }^{9}$

\section{Samuel Sulam's "Epistle of Joshua Son of Nun"}

Sulam cited a wide selection of sources in his glosses to Sefer Yuhasin. These include the Jerusalem Talmud (Zacuto 1963, p. 20), an Ashkenazi prayer book (Zacuto 1963, p. 36, 53), Sefer Yosippon (Zacuto 1963, p. 11) and our Samaritan story. He even cited the "the great priest" (הכומר הגדול) Augustine of Hippo's comment that Nero was the "Antichrist" (אנטיקרישטיו"). ${ }^{10}$ Sulam was clearly a broad reader. Near the end of the volume he appended an abridged Hebrew translation of Flavius Josephus's Against Apion, the first appearance of Josephus in Jewish publishing, as well as our tale of Joshua son of Nun. Introducing his anthology, Sulam writes:

Said Samuel: The soul of all flesh and every man with a wise heart will not know unsatiated joy when he finds a book of chronicles, for the soul rejoices and longs to read the books of the ancients, to acquire wisdom. Therefore, I saw fit to publish for the first time the Book of Yuhasim and afterwards I collected and assembled from the sheathes of all the books in gentile languages, Ishmaelites and Christians, and I assembled a book of memories, both long and short. I wanted to publish this short composition, for its purpose is to sanctify the Holy One of Jacob and his holy Torah and to increase his glory and that of he who received it from Sinai, the trusted of the house of our God, Moses our master, peace be upon him, and this I began with the help of the Almighty.

Introducing Apion, Sulam cites the fourth century Latin translator of Josephus, רופינו איקליניץ, Rufinus Aquileiensis, whose rendering appeared in Spanish translation in 1491 (and numerous times subsequently). Rufinus of Aquileia, Sulam tells us, marveled that 
Josephus, "born and raised in the mountains of Judah", acquired his broad acquaintance with classical literature, and "read so many books and felled all of their words to the ground and disproved them". Quoted by Sulam, his approbation of Josephus seems to reflect Sulam's own evident delight in collecting Jewish sources and publishing them. Sulam seems to compare himself favorably with Josephus, much admiring (citing Rufanus) "his broad acquaintance with classical literature". Sulam's interests even stretched to Samaritan literature.

Sulam introduces the tale of Joshua son of Nun with explicit reference to its Samaritan origin, even as he asserts that it was derived from a Jewish source:

Said S[amuel] S[ulam]: I found, I saw it in the Book of Chronicles of the Kuttim, that they remembered they had seen it in one midrash of the Jews (or alternately, "in one Jewish midrash". אמר ש"ש מצאתי ראיתי בספר זכרוני הכותיים וזכרו שראו אותו במדרש אמר של היהודים After Joshua's conquest of the Land of Israel and the killing of thirty-one kings, it happened that one of them had a prince of little Armenia and his name was Shubakh. He [Shubakh] arose and assembled the kings of Persia and Medea, forty-five kings. They took with them Yefet the hero, who stirred. They placed him over a number of men and gathered an army as numerous as the sand on the seashore. They sent a letter to Joshua, and this is the wording of the letter (וזה נוסח האגרת).

Where did Sulam find our story? His edition of Sefer Yuhasin was financed by an aristocratic woman of Istanbul, Esther Handali. Sulam refers to Handali as Esther Kiera, "Lady Esther", and writes correctly that she "stood high in favor at the court of the Sultan". Known for her philanthropy, Esther Handali "performed manifold services for the women in the harems of the Sultan and the Grand Vizir in Istanbul ... a reliable intermediary, personal emissary, translator and trustee at the highest levels". Sulam's circle of contacts were quite extensive. In fact, he remembers that Esther assembled scholars "around her table". 11

Opaquely, Sulam writes that "they remembered (וזכרו) that they had seen it [our story] in one midrash of the Jews". Who gave Sulam this testimonial? Were his sources Jews or Samaritans? Again, the evidence is frustratingly lacking. Could Sulam have been in communication with Samaritans? Joseph Scaliger, a pioneering French Protestant scholar of Samaritan studies, indeed did correspond with the Cairo community and his questions were passed on to Nablus. ${ }^{12}$ He acquired an Arabic copy of the Samaritan book of Joshua from Cairo in 1584. This is the manuscript published by Juynboll. We have no evidence of Samaritans in Asia Minor, but that may be just a historical lapse of memory. Significantly, Sulam spent some time in Egypt. ${ }^{13}$ Jews and Samaritans were in close proximity in early modern Cairo. Reinhard Pummer even suggests that their relations were "in general ... cordial". ${ }^{14}$ The sixteenth century Samaritan community was prosperous, and there was considerable local scribal activity. ${ }^{15}$ Egypt seems a reasonable place for Sulam to have encountered our story, just as Scaliger did through correspondence. Izhak Ben-Zvi suggests with some pride that "In Egypt, S. Sulam, the consummate scholar, had the opportunity to enter into direct negotiations with the Samaritans and to acquire from them books and copies of their writings - even before Scaliger - just as Samaritan sages could acquire Jewish sources, study them first hand, copy them and set them among their belongings". (Ben-Zvi 1947, pp. 135-36).

Suggestively, a Torah curtain "with six lines of Samaritan writing", that once hung "before the shrine in their [Samaritan] synagogue in Egypt" was donated by an anonymous Jew to a Jewish synagogue in Bornova, near Izmir, suggests that Sulam's volume was not the only Samaritan object to fall into Jewish hands at this time. This curtain is discussed in a responsum of Istanbul rabbi Jacob Tam b. David ibn Yahya (born Portugal, died 1542), who knew quite a bit about the Samaritan synagogues in both Damascus and Cairo-and found reason to reject the use of this textile. ${ }^{16}$ Sulam, by contrast, accepted the Samaritan 
story as authentically Jewish, and like the rebuffed donor of the curtain, did not try to hide the Samaritan source of his find.

Most significant for our purposes, a Judeo-Arabic fragment of our tale was found in the Cairo Geniza. This document, published by Friedrich Niessen in 2002, preserves "some lines of Joshua's letter to his opponent before the ongoing battle". ${ }^{17}$ The text is close to the version presented in Juynboll's Samaritan Book of Joshua, though the versions are independent. ${ }^{18}$ A version of this story was thus in circulation among medieval Arabic-reading Jews even before Sulam's discovery of the Samaritan text. Niessen goes so far as to suggest that "If one were to rule out the possibility that the fragment reached the Cairo Geniza purely by accident one could conclude that at least the Shaubak legend, which had its own 'Traditionsgeschichte' before being integrated into the context of the Samaritan chronicles, was popular - albeit in Arabic and not Hebrew - among both communities and the knowledge of it was more widespread than hitherto recognized". (Niessen 2002, p. 233). If this is correct, Ginzberg's well developed nose for discovering Jewish sources in unexpected places has once again proven itself. ${ }^{19}$ I would not be surprised had Sulam conferred with other Jewish scholars, who recognized the story from such a Judeo-Arabic version (or even a yet to be discovered Hebrew or Aramaic version), telling Sulam that "they had seen it in one Jewish midrash". Both Elhanan Nathan Adler and Moses Gaster, however, reasonably assumed that it was Samaritans who made this identification. Alas, the "they" who identified the tale as Jewish for Sulam remains obscure (Adler 1908, p. 1147; Gaster 1908b, pp. 1153-54).

\section{Sulam's “Epistle of Joshua Son of Nun" and Its Samaritan Sources}

The Epistle-iggeret-reproduced by Sulam is somewhat longer than Ginzberg's text. Kirchheim in turn chided Sulam's propensity for condensing sources, suggesting that here too he abridged the text of Samaritan Joshua. Ben-Zvi posits, though, that Sulam may have translated an independent text. ${ }^{20} \mathrm{Abu}$ al-Fath drew on numerous sources in his 1355 chronicle, the Kitāb al-Tarīkh, which contains our story. He remembers having "found a longer version of this [letter] in a longer Chronicle". Abū al-Fath informs us that "for the sake of a concise summary I have condensed it along the lines of what I found in an old version". (Stenhouse 1985, chp. 5, p. 26).

Philologist Moshe Florentin has suggested to me that "The language style [of Sulam's Epistle] is quite different from what we know about the late Samaritan compositions that we possess. Who composed it? God knows, at least for the time being. I doubt it was a Samaritan". ${ }^{21}$ Ben-Zvi correctly concluded in 1947 that "we cannot determine categorically that he [Sulam] spoke of a version in Samaritan Hebrew. It is likely, though, that Sulam came upon an Arabic text in Samaritan script". (Ben-Zvi 1947, p. 134). Gottheil and Seligman wrote already in The Jewish Encyclopaedia that "It is evident that Shullam saw it in an Arabic work, probably the Samaritan Book of Joshua, for he reads "Yaniah" instead of "Nabih", a change possible only if the original was in Arabic characters". (Gottheil and Seligman 1901-1906). Hebraisms drawn from later books of the Prophets and Writings appear in this Jewish translation, ${ }^{22}$ which would not occur in Samaritan texts (Samaritans revere the Pentateuch, and not the remaining books of the Jewish canon). In accepting our tale as originally Jewish, Ginzberg would certainly have noted this linguistic point. In addition, the chronicler's use of the Jericho narrative of Joshua 6 and the identification of the general Shaubak with a general mentioned in 2 Samuel 10: 16 and 18, a Syrian defeated by David, might lead in this direction (see Ben-Zvi 1947, p. 139). In general, though, Samaritan chronicles did use the Jewish Bible as a source, writing a partisan Samaritan counterhistory to the Jewish story. The story preserved by Sulam contains no overtly Samaritan markers. There is no explicit mention of Mt. Gerizim or that the battle was Scarrayed in the plain before it - as there is in Samaritan versions. In Sulam's version the battle is to take place "in the hills of Ephraim". Even this Samaritan allusion was shorn off by Ginzberg. Distinctly "Jewish" markers, plus the paucity of explicitly Samaritan ones, must certainly have drawn Ginzberg's attention to Sulam's story - which he then "improved". 
Other elements of Sulam's story nonetheless point to Samaritan themes. Joshua responds to his attackers with an opening formula ubiquitous in Samaritan texts (including the introduction of Abū al-Fath), reminiscent of Islamic formulae: "In the Name of the Lord, the God of Israel".$^{23}$ That Joshua calls on the tribes across the Jordan for help fits a Samaritan context well. It is not Judah that came to the rescue, but the northern tribes, including the Josephite tribe of Manasseh. It is significant that the hero of the story is Phinehas son of Eleazar son of Aaron the Priest-Samaritan hero par excellence. Phinehas possessed "the covenant of eternal priesthood" (Numbers 25, pp. 11-12) and is the reputed ancestor of all the high priests, until his line ended in 1624 (Pummer 2016, p. 166). Echoing the biblical Joshua at Jericho, Phinehas "arrived, and, at the sound of his trumpets, the walls toppled down". Even at this most consequential moment in Joshua's conquest, then, the priesthood is the most important authority in Samaritan life, even more powerful than the giant Joshua son of Nun and the witchcraft of Shaubak's mother. Were no Samaritan version of this story extant beyond Sulam, a reader might well posit a Samaritan context.

\section{The Epistle of Joshua Son of Nun: From Constantinople to Yiddish Literature}

Immediately following the "Epistle of Joshua Son of Nun", and at the bottom of the very last page of the first edition of Sefer Yuhasin (Zacuto 1566), Sulam provides his rationale for including this text:

Said Samuel Sulam: I found a sign in the verse "until the Lord gives rest to your brethren as well as to you, [and they also take possession of the land which the Lord your God is giving them; then you shall return to the land of your possession, and shall possess it, the land which Moses the servant of the Lord gave you beyond the Jordan toward the sunrise]" (Joshua 1:15).

Sulam placed our Epistle at the end of his volume in order to conclude with an uplifting hope for rest and redemption - a poignant message to his fellow Iberian exiles a mere sixty-nine years after the Jewish expulsion from Portugal in 1497. His comments replace Zacuto's own conclusion, preserved in manuscript. This text similarly reflects messianic hope using traditional Jewish tropes:

The book of Yuhasin and the chronicle of all that happened to us in days past is completed, [a tale of] miracles and wonders. May the Omnipotent One, blessed be $\mathrm{He}$, do miracles and wonders for us, for good, and take us out of darkness to light. He will bring us our righteous Messiah, and redeem us soon, Amen, may we be strong and strengthened ... Amen.

Zacuto's own conclusion was left unpublished by Sulam, likely owing to the authors uncomplimentary descriptions of Muhammed, Islam and the Ottomans. ${ }^{24}$

The "Epistle of Joshua son of Nun", with Sulam's messianic concluding gloss, appears in all subsequent editions, though after the first edition, further additions pushed our tale increasingly toward the center of the volume. Subsequent publishers expanded Sulam's anthology with their own additions - beginning with the second, Cracow edition of Sefer Yuhasin (Zacuto 1580). ${ }^{25}$ Building on Sulam's messianic rhetoric, the editor of the Cracow edition, Samuel Boehm, continues immediately with a selection from Abraham Farissol's hope-filled description of David Reuveni and the much looked to powerful and militaristic Jews of the east. ${ }^{26}$ This text is drawn from his Orhot Olam, "The Book of the Ways of the World", which first appeared in Farissol (1524): ${ }^{27}$

News: I tell here what I found in the book Orhot Olam, which Rabbi Abraham Farissol copied and composed. He is the author of a commentary on Job. I saw fit to attach it to Sefer Yuhasin to dress the wounds and revive the hearts of the dejected sufferers of this bitter and long exile, which, through our many sins, is 1512 years long. Before me is our holy Torah and our enemies mock us, saying that our hope is lost and we have been judged. We have no prophet, and none of us has any idea until when. "A king's glory is in the greatness of his people, 
and peoples' greatness" (Proverbs 14:28). Behold, owing to our sins we are left few where we were many, "without king or prince [without sacrifice or pillar, without ephod or teraphim (Hosea 3:4)". Though we are pressed and cry for help, we have our brothers, our redeemers, the ten tribes ... .

The editor powerfully asserts contemporary Jewish resistance and even hopes of power among the dispersed Spanish exiles. This assertion follows upon the paradigmatic victory of Joshua son of Nun of our story - he against the odds.

The Prague scholar Reuben ben Hoshke Sofer included our tale in his Yalqut Reuveni (Amsterdam 1681) as a comment on Joshua 1:15, "until the Lord gives rest to your brethren as well as to you, and they also take possession of the land which the Lord your God is giving them ..." ". Sofer included Sulam's glosses and cites Sefer Yuhasin as the source of the story. ${ }^{28}$ Sulam's story was published in the many subsequent editions of both $S e$ fer Yuhasin and Yalqut Reuveni. ${ }^{29}$ Our tale was released from its Yuhasin context in a rather rare collection of legends called Lequtei ha-Ma'asim, published in Verona earlier, in 1648. Sulam's introductory and concluding notes are removed, and the tale is now independentits Samaritan origins forgotten. It was now called "A legend that occurred in the time of Joshua, after conquest of the Land of Israel and the slaughter of thirty-one kings". ${ }^{30}$ The story is introduced unproblematically as "A legend that happened (מעשה שהיה) to a king who had one son, who ruled over Armenia Minor ... ".

Parallel to its appearance in Hebrew literature, Sulam's story appeared in Yiddish translation. $^{31}$ This was noticed by Chava Turniansky in an 1669 Yiddish version of an influential early sixteenth century rewritten Bible called (Sefer ha-Yashar 1625; Dan 1986). The Yiddish volume was called Tzemah David. ${ }^{32}$ This text was prepared by one Abraham Kopserlish, a refugee from Ukraine living in Germany (apparently in Cleves), and includes a translation of the Samaritan chronicle as well (Kopserlish 1669; Turniansky 1985, pp. 58789). Our tale appears after a précis of a chapter on Joshua son of Nun. Kopserlish wove Sulam's Joshua story into the body of Tzemah David and even expanded it. Where Sefer haYashar concludes with Joshua's conquest, Tzemah David continues with our Epistle. This translation was never published, though it was prepared for publication. The only existing manuscript is in the collection of the Jewish Theological Seminary, and alas, the end of the story is missing.

Jacob ben Mattithiah ha-Levi published a translation of our tale in his Yiddish version of Sefer ha-Yashar, under the title Sefer Tam ve-Yashar (1674, Frankfurt am Main, and reprinted in a number of editions). ${ }^{33}$ Jacob appended a Yiddish translation of the Samaritan chronicle to Sefer ha-Yashar's discussion of Joshua, after the conclusion of that volume (Turniansky 1985, p. 587). This appendix refers to Sefer Yuhasin and to Sulam, omitting reference to the Samaritan origins of the story. This addition and others were proudly heralded by the publisher on the frontispiece of this volume. Turniansky emphasizes the fact that each author chose to add the "Epistle of Joshua Son of Nun" to his Yiddish publications, which "clearly testifies to the close cultural connection between the biblical story and the late story from Sefer Yuhasin, and the dissemination of Rabbi Abraham Zacuto's [sic] story in Ashkenazi culture of the seventeenth century". (Turniansky 1985, pp. 599600). Appended to the Yiddish versions of Sefer ha-Yashar Sulam's tale provided a thrilling ending - a crescendo - to a story that begins at creation and climaxes with the final victory of Joshua son of Nun.

\section{19th and 20th Century Developments}

We next hear of the Epistle in Kirchheim's academic publication, Karme Shomron. Kirchheim reproduced Scaliger's manuscript as published by Juynboll in a Hebrew translation based on the Arabic and Juynboll's Latin translation, noting Sulam's citation of this tradition. Kirchheim, as we have seen, rejected Sulam's identification of the story as Jewish. He rightly noted that other than Sulam, "this story is not cited by any [Jewish] author nor is there any hint of it in our literature, nor in that of other nations". (Kirchheim 1851, p. 55). He was quite sure that this is originally a Samaritan tale, having no knowledge of the Ge- 
niza text. Gaster, Ginzberg's senior colleague, in contrast, was quite certain regarding the Jewish origins of our story, going so far as to say, on the basis of Sulam and some Jewish parallels, that "it must have existed in a Jewish book of Biblical Legends". (Gaster 1908b, p. 1154).

Ginzberg clearly agreed, and included it in his work. Still, as Rebecca Schorsch notes, in Legends, Ginzberg "is overwhelmingly concerned with demonstrating the Jewish contribution, and Jewish originality, rather than a world of cultural interaction and mutual influence". ${ }^{34}$ Ginzberg was particularly attracted to "texts richer in images with the ability to conjure up a vision", and like other folklorists writing for general audiences at his time makes up details within his narrative "to render his stories more legend-like". ${ }^{35}$ The Epistle of Joshua son of Nun seems to have been too good for Ginzberg to pass up - as it was for Sulam before him. Ginzberg follows the model set by the Yiddish versions in his telling of Joshua's conquest. Like them, he climaxes the conquest of the promised land with Sulam's tale. In a sense, Sulam provided our story with a "kashrut certification", or perhaps the "naturalization papers" that facilitated its inclusion in the Jewish story by early modern publishers, and followed by Ginzberg.

It is noteworthy that Samaritan sources are virtually absent from Legends of the Jews. From the earliest levels of the Samaritan "midrash", Tibat Marqe, which date to the fifth century, its later layers, to the rich array of Samaritan piyyut and exquisite chronicles, the literature of the Israelite Samaritans was not engaged by Ginzberg. ${ }^{36}$ The essentials of this literature were well published, as I have noted, particularly by Ginzberg's senior colleague Moses Gaster and other prominent members of the international Jewish culturalist community with whom he was most certainly acquainted, and in America by James Allan Montgomery (1907). ${ }^{37}$ More than that, Ginzberg's own Jewish Theological Seminary houses a major collection of Samaritan manuscripts, procured during his tenure at that institution (1902-1953). ${ }^{38}$ Unraveling these threads and distinguishing the Jewish from the Samaritan in Samaritan sources, as Ginzberg's approach to patristic sources would demand (Ginzberg 1900), would often be impossible-and so theologically ambiguous for Rabbi Ginzberg. The omission of Samaritan sources-especially from the scholarly apparatus, stems, it seems to me, from a traditionalist theological/cultural bias-even antagonism(or perhaps just blindness) regarding the literature of the "other" Israel.

Following on Amoraic sources and a medieval and modern rabbinic consensus, ${ }^{39}$ the few references to Samaritans in Ginzberg's narrative are quite negative. This selection is similar to that of H. N. Bialik and Y. H. Ravnitsky in their now-canonical Sefer ha-Aggadah, “The Book of Legends" (Bialik and Ravnitzky 1908-1911). ${ }^{40}$ Bialik and Ravnitsky preserve some of the actual complexity of the rabbinic texts from which the sources are extracted, even as they merge versions of stories and often enhance their polemical content. ${ }^{41}$ The lack of literary contexts for each source cited makes Ginzberg's deployment of these traditions seem all the more negative. Instructively, Judah David Eisenstein, a New York Hebraist, traditionalist stalwart, an acquaintance of Ginzberg and his colleague at the Jewish Encyclopedia, also could not resist. He included our tale in his 1915 anthology Ozar Midrashim. Eisenstein expressed both deep ambivalence toward - and fascination with - the Samaritans. ${ }^{42}$ He began his introduction to our story by describing its Samaritan origins, consigning Sulam to a footnote. Eisenstein's description suggests a fraught balance between overtly expressed religious traditionalism ("Conservativism", as he calls it), Americanism and a sort of maskilic cultural Zionism associated with the pre-Herzl Hovevei Zion movement. ${ }^{43}$ His knowledge that Sulam's tale derives from Samaritans tugs at Eisenstein's modernist aesthetic, with concern that earlier generations could elide through erasure of this information from Sulam's introduction.

Unlike the cultural Zionism of Ahad Ha' Am's circle (or Kirchheim before them), neither Eisenstein nor Ginzberg embraced the Samaritans. This was not unusual in maskilic circles. An article by Menachem Mordechai Silman in an anthology meant for "youths" that was edited by Y. H. Ravnitsky (Silman 1900), for example, is blistering in its scorn- 
fully disparaging portrayal of Samaritans. ${ }^{44}$ After mentioning the Samaritan Joshua as a נוסחא משונה, a "strange version", and the versions published by Lunz, Gaster and Kirchheim, Eisenstein writes: "It is known not to rely on the Samaritans, for they used to falsify the Torah to strengthen their belief in Mt. Gerizim, and wrote lying books (ספרים כוזבים) - this even as he then reproduces the "Epistle of Joshua Son of Nun" from Sulam.45

The work of Ginzberg and Eisenstein was in marked contrast to another contemporary - the more radical, individualistic, "secular", ${ }^{46}$ anti-clerical, internally focused culturalist scholar, Micha Yosef Berdyczewski-known by the pen name Micha Bin Gorion (died 1921). Dan Ben Amos writes of Berdyczewski that he "searched not for an ideal construction of traditional Jewish thought but for the actual multifaceted realities of Jewish life". (Ben Amos 1990, p. xxxvi; Schorsch 2003, p. 26). Unlike Ginzberg in his new narrative, Berdyczewski showed interest in Jewish traditions supposed to be preserved beyond "Israelite" literature. In this ideologically charged anthological project, Berdyczewski $(1914-1927,1939)$ included writings by every sort of Jews, plus Samaritans. He quietly and without fanfare included passages from Samaritan chronicles in his anthologies of diverse "Israelite" legends, Die Sagen der Juden (1914-1927) and Mimekor Yisrael (1939). ${ }^{47}$ Berdyczewski "ingathered" the literature of this "branch of Israel" as part of his secularized Zionist "messianic", project-which increasingly included the Samaritans in the Israelite polity. Some European and Palestinian cultural Zionist-notably Ahad Ha'Am, David Yellin, and most of all Moses Gaster and Izhak Ben-Zvi, were at the same time also folding the Samaritans into the Zionist polity (Ahad Ha' Am 1887). ${ }^{48}$

Berdyczewski's Mimekor Yisrael, edited by his son Emanuel after his death, tellingly reproduced our tale as מלחמתו האחרונה של יהושע, "The Last War of Joshua". (Berdyczewski 1956, pp. 97-98; 1965, pp. 50-52). Mimekor Yisrael labels this and two other sources as Samaritan, ours as "A Samaritan Source". (Berdyczewski 1965, pp. 97, 109). These are among the few stories in this anthology that are sourced in their introductory titles. Fully represented in his carefully curated collection, Berdyczewski "others" the Samaritan sources by flagging them-where Ginzberg fully naturalized our tale. Berdyczewski's note reports that our story is reproduced from Gaster's Hebrew Samaritan Joshua (Gaster 1908a). He cites Lequtei Ma'asim, Kirchheim's translation into Hebrew from Arabic, and notes "another tradition" (meaning Sulam) reproduced by Eisenstein and Ginzberg. ${ }^{49}$ Maintaining the very Samaritan-ness of this source, Berdyczewski reproduces references to Mt. Gerizim without elision. Berdyczewski was a nationalist revolutionary inspired by Nietzsche, and so our story of Israelite power must have appealed to him. Intellectually, Ginzberg and Eisenstein represented an earlier generation. Eisenstein disparately but accurately referred to Berdyczewski as "one of the new maskilim". Berdyczewski's own publishing house, of course, was called הצעירים, "The Youths".

Ginzberg's rabbinic conservatism in the narrative of Legends is in marked contrast to his emphasis in his notes on Classical authors, Christian sources and the Apocrypha and Pseudepigrapha-all preserved by Christians. Scholarship on Patristic parallels to Rabbinic sources had a long pedigree even before Ginzberg's work, going back to Heinrich Graetz (1854-1855). These sources were clearly Ginzberg's window out of his traditional Eastern European elite education, and his own attempt to meld his increasingly complex elite rabbinic/wissenschaftlich/American identity. ${ }^{51}$ In an early review of Berdyczewski's Die Sagen der Juden, a book published, as often happens, with virtually the same title in the same year as Ginzberg's first volumes, Australian Jewish folklorist, Jewish Encyclopedia "revising editor" and Jewish Theological Seminary faculty member Joseph Jacobs noted this difference. ${ }^{52}$ In his essay, entitled "Jewish Legends", this renowned scholar of English folklore implicitly praises Ginzberg - and derides Berdyczewski-without acknowledging Ginzberg's own elisions: "Samaritan and Karaitic versions of legends are occasionally given [by Bin Gorion]. On the other hand, the large quantity of material given in the Hellenistic sources is entirely ignored, and no attempt is made to utilize the Christian pseudepigraphic literature and the Church Fathers". ${ }^{53}$ "Discovering" cultural links with Christianity, even the claim of Jewish influence at the root of Western culture were not unique to 
Ginzberg in early twentieth century America-a community desperate to shed its subalternaity. ${ }^{54}$ Alternately, Hungarian folklorist Bernhard Heller noted that Islamic sources are cited less often than one might anticipate (Heller 1933-1934, pp. 393-418). Both Ginzberg and Jacobs reflect a preference for Christian sources over Islamic exempla-surely an inherent orientalism both in their attitudes toward Samaritans and then in Western culture's attitudes to them as Jews. ${ }^{55}$ Prioritizing kinship with things Christian was a statement of their own predicament as Jewish scholars, representatives of their community. Then, as now (Fine, forthcoming), forging cultural links between rabbis and Classical and Christian authors valued by the Western elite carried far more prestige value and cultural currency in American and European academic circles that Ginzberg and his generation were so desperate to join. Samaritan connections (or for that matter, ties to Islam) were not very useful to this Emancipation project. ${ }^{56}$

Interest in our story by Louis Ginzberg, Judah David Eisenstein and Micah Joseph Berdyczewski speaks to the shared ethos of these cultural Zionist anthologizers. Each, in his own way, integrated the "Epistle of Joshua Son of Nun" into their national stories/anthologies as the highpoint of Joshua's conquest of the Land. This modern absorption occurred at a moment when the shock of the Kishinev pogrom was fresh (Zipperstein 2018) and the assertion of Jewish national "regeneration" and dreams of power, were in the air-just as hopes of "redemption" were for Sulam and his "exiled" Sephardi compatriots centuries earlier. The story of Joshua's conquest was formative to Jewish conceptions of exile and redemption, and thus meaningful to the Zionist ethos. ${ }^{57}$ Jabotinsky's Jewish Legion (1918-1921), whose conquest of the Holy Land was described in 1918 as occurring "within a short distance of where their forefathers, under Joshua, first crossed into Palestine", was a twinkle in the Zionist eye. ${ }^{58}$ In modern times, our tale has functioned similarly to the far more significant Sefer Yosippon, a popular medieval Hebrew translation and rabbinicization of a Latin epitome of Josephus' Jewish War (Flusser 1980). Yosippon was published in Istanbul a mere thirteen years after the expulsion from Portugal (1510). It was known to Sulam, who in introducing Apion, called Josephus Yosef ha-Kohen ben Gurion, the traditional name of the author of Yosippon. For generations, Yosippon has been read avidly by Jewish dreamers -including, by and by, Micha Yosef Berdyczewski and by a teen named David Gruen. It was so influential that both styled their Hebrew surnames, Bin Gorion/Ben Gurion-after the supposed author of Sefer Yosippon (Bowman 1995, pp. 40-45; Holtzman 1995, p. 306). The "Epistle of Joshua Son of Nun", too, was popular among literati of these circles. It is noteworthy that David Ben Gurion's copies of Yosippon and Sefer Yuhasin are preserved to this day in his extensive personal library in his Tel Aviv home (along with copies of Legends of the Jews, Mimekor Yisrael and Sefer ha-Aggadah). ${ }^{59}$

\section{Concluding Comments: From Samaritan Tale to Jewish Legend}

As if the path of the "Epistle of Joshua Son of Nun" from a Samaritan tale to a Jewish legend were not sufficiently complex, our story took one more twist of note. In 1912 Haim Bedjerano, then chief rabbi of Adrianapolis in Turkey, described in an Istanbul Zionist newspaper, ha-Mevaser, a manuscript written in an odd Samaritan script containing Sulam's text of our tale-complete with its Jewish hebraicisms. ${ }^{60}$ Ben-Zvi found another copy in Damascus, determining that fake Samaritan manuscripts were produced there by a particular Jew for sale to Westerners. ${ }^{61}$ This manuscript was clearly meant to be sold as the original Samaritan text discovered by Sulam! (Ben-Zvi 1947, pp. 132, 139). The scheme was aborted owing to Bedjerano's article. Only the absolute scribal clumsiness of the forgers, their lack of philological sophistication, and the diligence of Rabbi Bedjerano and then of Ben-Zvi kept these forgeries out of the libraries of Europe and America and out of the academic conversation. Just as interesting was the assumption by these forgers that their creation - the Samaritan "original" of Sulam's text-would be valuable to Westerners.

Modern scholars have pointed to numerous instances where Samaritan culture absorbed and transformed Jewish sources. Rarely is the reciprocal considered-of Jews drawing religious sustenance from the Samaritans. The Samaritan minority culture to the Jew- 
ish minority culture is always portrayed as the recipient, seldom the source of influence. Sulam's introduction to our story is a complicating case, and to my mind a caution against arbitrarily assuming one-way-influence from the larger group to the minority. This is a caution with broad implications across the long Samaritan-Jewish encounter, even as it reflects the cosmopolitanism of sixteenth century Jewry. The "Epistle of Joshua Son of Nun", identified as Jewish literature by Sulam, regularized by Lequtei ha-Ma'asim and by Sofer in his Yalqut Reuveni, appeared in Yiddish translation and was finally adopted by Ginzberg, Eisenstein and Berdyczewski. This is a unique, documented example of Samaritan influence upon Jewish literature-both traditional and modern-made all the more complicated by a frustratingly fragmentary Judeo-Arabic document from the Geniza. Its message of Israelite redemption and power must have offered succour to the powerless exiles from Spain and Portugal, just as it did to later generations of Jews - and of course, to the Samaritans across their long history.

Funding: This research received no external funding.

Acknowledgments: This article is for Menachem Mor. Many thanks to Yaakov M. Fine, Leah Bierman Fine, Moshe Florentin, David Golinkin, Galit Hasan-Rokem, Joseph Hacker, Joshua Karlip, Baruch Lev Kelman, Jess Olson, Benjamin Outhwaite, Ronnie Perelis, Reinhard Pummer, Andrea Schatz, and especially David Selis for their contributions that made this a better article.

Conflicts of Interest: The authors declare no conflict of interest.

\section{Notes}

Often referred to as Shulam and Shullam.

See, however, Heinemann (1973); Shinan (1987, pp. 113-17) and especially Mishor (2000).

See also 6: 202, n. 103.

Stenhouse (1985, pp. xxiv-xxxv) discusses the publication history of this document. See Niessen (2000) and Farber (2016, pp. 254-71).

5 Bloch and Pratt (1936, p. 473). Gottheil's prominence in Jewish studies at this time has been underestimated in the current origins myth history of Judaic Studies in the United States and deserves reevaluation. As a first step, see Greenspahn (2000).

6 Gottheil and Seligman (1901-1906, p. 289).

7 (Hacker 2017, p. 84). On the importance of publishing as a vehicle of cultural transmission, communication and reconstruction by the Iberian exiles (Hacker 2012).

8 Hacker (2017) provides a concise history of Ottoman Jewry of this period.

9 Zacuto (1963, pp. 60-61). See the comments of Filpowski in Zacuto (1963, v.); Freimann in Zacuto (1963, xx-xxi); Deutsch and Mannheimer (1901-1906); Schatz (2019, pp. 98-99).

Zacuto (1963, p. 42), explaining Antichrist as המך דתם, "he who will afflict their religion". See Augustine, City of God, 20.19.3.

See Sulam's preface to the first edition, reproduced in Zacuto (1963, pp. xvi-xvii) and Shpigel (1998).

Narrated by Anderson (1989, pp. 103-5).

Ben-Zvi (1947, pp. 135-36), my translation. Joseph Hacker will discuss Sulam and his time in Egypt in a forthcoming article. He kindly shared this information with me in an email dated 11 November 2020.

Pummer (1998, pp. 227-30, here p. 228); Brüll (1885).

15 Sulam knew of a second work by Zacuto, "which is found in Damascus", suggesting the reach of his contacts (Freimann, in Zacuto 1963, xix).

16 Tam (1622), responsum 204, translated by Kelman (forthcoming).

17 T-S NS 188.20, published by Niessen, 2002. Benjamin Outhwaite of the Genizah Research Unit, Cambridge University Library, informs me that "if I had to guess, I'd go with our standard line that it belongs to the 'Classical Period' of the Genizah (based on the hand and the relative crudeness of the paper), and therefore 11-13th c., with earlier in that time rather than later being most likely: 11-12th c.?" (e-mail, 5 October 2020).

Niessen (2002, p. 232) is absolutely correct that "A desideratum for the studies of the Samaritan chronicles is a comprehensive synopsis and concordance of all extant versions ...".

19 This appreciation permeates Heller's review. See especially 25.1 (Heller 1933-1934), pp. $29-52$. 


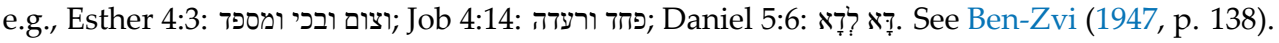

See, for example, Pummer (1993, p. 30).

Neubauer (1909, p. 118), reproduced in Zacuto (1963, L).

Filpowski in Zacuto (1963, v); Freiman in Zacuto (1963, xx).

On Boehm's edition and his inclusion of citations from Farissol (Schatz and Sládek, forthcoming). On Farissol (Ruderman 1981). Sefer Yuhasin, Zacuto (1580, p. 153 (39b)); Zacuto (1963, p. 58).

Cited from Yalqut Reuveni (1700, pp. 155b-156a); Ginzberg (Ginzberg 1909-1938) 5:138, n. 16; 358, n. 310; 6:407, n. 56.

On Yalqut Reuveni as an anthology, Elbaum (2014, pp. 65, 67-68, 71).

(1648, unpaginated pp. 51-56), cited by Berdyczewski (1965, n. 46, p. 502).

Turniansky (1985, p. 586). Many thanks to Andrea Schatz for bringing this fascinating turn to my attention.

Owing to Covid closures, I was unable to view this manuscript.

e.g., Sefer Tam ve-Yashar (1768). Fürth: Hayyim b. Hirsh; Sefer Tam ve-Yashar (1783). Sulzbach: Zekl b. Aharon.

Schorsch (2003, p. 13, n. 17). See also 206, n. 13: “Ginzberg, as I argue in my work, largely glosses over differences in favor of uniting the disparate features of Jewish (and often, non-Jewish) culture". See in general Schorsch (2014).

Schorsch (2003, p. 162, n. 41); See G. Fine (1987, pp. 89-90).

Ginzberg 1936, index, s.v. Samaritans. For the complexity of rabbinic interactions with Samaritans, see (Schick and Fine forthcoming), and the bibliography there.

Ginzberg corresponded with Gaster and sent him the last two volumes (3-4) of Legends. See Golinkin (2014, p. 21).

Jewish Theological Seminary 2000, presents a selection of the JTS collection.

For a traditionalist statement of rabbinic attitudes, Ehrlinger (1947-2018, vol. 27, pp. 649-730).

(Kiel 1997); Elbaum (2014, pp. 72-75) and Hasan-Rokem (2014, pp. 81-82) discuss the Zionist anthological projects that were underway at the same time as Legends. On Sefer ha-Aggadah (Elbaum 1987). Eisenstein (1915), is a less noticed example of this phenomenon. On Eisenstein, see Oser (2020).

On the narrative of Legends, see Ginzberg (1909-1938, 5: pp. vii-viii); Schorsch (2003, pp. 18-41, 125-98); Hasan-Rokem (2014, pp. 79-88), who rightly describes Legends as a Jewish imaginaire (p. 88), following on Ginzberg himself, who describes “Jewish Legend" as a place "in which Jewish imagination expressed itself in regard to biblical events, persons and teachings" (5: p. viii). See for example, Eisenstein (1920, pp. 338-39), who is clearly fascinated by Samaritans (even illustrating the Passover sacrifice with a photograph) and yet feels the need to disparage them.

On Ginzberg's Zionism, E. Ginzberg (1966, pp. 187-213).

(Silman 1900). Many thanks to Yehuda Mirsky and David Selis for bringing this volume to my attention.

My translation. Eisenstein (1915, p. 209); Oser (2020, pp. 76-84, 93, 291-93). On American Protestantism and the Samaritans (Schwartz, forthcoming).

On the idea of Jewish "secularism" in Zionist and early Israeli culture (Barak-Erez 2007).

See also Berdyczewski's (1926), Sinai und Gerizim.

(Ahad Ha'Am 1887). See the following representative works: Gaster (1925); Ben-Zvi (1934); Yellin (1907-1908).

(Gaster 1908a). For Eisenstein's correspondence with Berdyczewski, see Oser (2020, pp. 101-2).

Oser (2020, p. 291); Holtzman (1995, p. 306).

Unstated in Eli Ginzberg's (1966) reminiscences of his father, this liminal positioning was clearly central to Ginzberg's identity. On Jacobs, see Sulzberger (1917, pp. 72-73); S. Schwartz (1991, passim).

Jacobs (1914, p. 500). In a public conversation on the pages of the Monatsschrift für die Geschichte und Wissenschaft des Judenthums Heller and Gaster (1933) debate the extent of Islamic influence on Samaritanism and Judaism. Gaster asserts a minimalist position (pp. 304-5).

e.g., Ginzberg's friend and Harvard faculty member Harry A. Wolfson, who argued that Jewish philosophy was the germinating point of western Philosophy and scholars who imagined that Roman period Jewish art and architecture was the starting point for Western artistic tradition. On Wolfson, see (Runia 1984). On Jewish architecture, see Fine (2010, pp. 16, 32-33).

On "Orientalism" in the German academy in which Ginzberg was formed as a Western scholar, Marchand (2013). Ginzberg's elision is notable, as the scholarship of his teacher Theodor Nöldeke focused on early Islam (pp. 174-78). On this relationship, Newman (2010, pp. 183-84). Many thanks to Galit Hasan-Rokem for helping me to sharpen this point. For a useful summary of the Jewish Emancipation project in twentieth century America, Sorkin (2019, pp. 346-53). Regarding over-focus on Christianity in the study of ancient Judaism, Fine (2020, p. 257, n. 56).

On Joshua in Jewish thought, Farber (2016). See now Havrelock (2020). This presentist and polemical volume misrepresents historic Jewish engagement with the book of Joshua, arguing incorrectly - as even my short essay shows - that "the book of Joshua was largely ignored and reviled by diaspora Jews". 
Keren and Keren (2010), and the bibliography here. For comparison of the Jewish Legion with the ancient Israelites under Joshua, see, for example, Patterson (1922, pp. 130, 192).

61 Ben-Zvi's manuscripts are preserved in in the collection of Yad Ben-Zvi Institute, Jerusalem.

\section{References}

Adler, Elhanan Nathan. 1908. On the Samaritan Book of Joshua. Journal of the Royal Asiatic Society, 1143-47. [CrossRef]

Ahad Ha'Am. 1887. A Small Schoolbag. HaShiloah 1: 388-89. (In Hebrew).

Anderson, Robert T. 1989. Samaritan History during the Renaissance. In The Samaritans. Edited by Alan D. Crown. Tübingen: Mohr Siebeck, pp. 95-112.

Barak-Erez, Daphne. 2007. Outlawed Pigs: Law, Religion, and Culture in Israel. Madison: The University of Wisconsin Press.

Ben Amos, Dan. 1990. Micah Joseph Berdyczewski. In Mimekor Yisrael: Classical Jewish Folktales. Bloomington: Indiana University Press, pp. xxix-lxv.

Ben-Zvi, Izhak. 1934. Sefer ha-Shomronim. Tel Aviv: A. Y. Stiebel.

Ben-Zvi, Izhak. 1947. Sefer Yehoshua ve-Ziufo he-Høadash. Knesset Divre Sofrim le-Zekher H. N. Bialik 10: 52-130.

Berdyczewski, Micah Joseph. 1914-1927. Die Sagen der Juden. Translated by Rahel Bin-Gorion. Frankfurt am Main: Rütten und Loening.

Berdyczewski, Micah Joseph. 1926. Sinai und Gerizim: über den Ursprung der Israelitichen Religion. Edited by E. Bin Gorion. Berlin: Morgenland.

Berdyczewski, Micah Joseph. 1939. Me-Mekor Yisrael. Edited by E. Bin Gorion. Jerusalem and Tel Aviv: Bialik Institute and Dvir.

Berdyczewski, Micah Joseph. 1956. Tsefunot ve-Aggadot. Tel Aviv: Am Oved.

Berdyczewski, Micah Joseph. 1965. Me-Mekor Yisrael. Edited by E. Bin Gorion. Jerusalem and Tel Aviv: Bialik Institute and Dvir.

Bialik, Hayyim Nahman, and Joshua Chana Ravnitzky. 1908-1911. Sefer ha-Aggadah: Mivhar ha-agadot sheba-Talmud uva-midrashim sedurot le-fi ha-'inyanim u-meforashot. Odessa: Moriah.

Bloch, Joshua, and Ida A. Pratt. 1936. Richard James Horatio Gottheil 1862-1936. Journal of the American Oriental Society 56: 472-89.

Bowman, Steven. 1995. 'Yosippon' and Jewish Nationalism. Proceedings of the American Academy for Jewish Research 61: 23-51.

Brüll, N. 1885. Die Samaritaner in Kairo. Jahrbücher für Jüdische Geschichte und Literatur 7: 43-45.

Crane, Oliver. 1890. The Samaritan Chronicle of the Book of Joshua, the Son of Nun. Translated by Arabic. New York: John Alden.

Dan, Joseph, ed. 1986. Sefer HaYashar. Jerusalem: Bialik Institute.

Deutsch, Gotthard, and S. Mannheimer. 1901-1906. Samuel Shullam. In The Jewish Encyclopedia: A Descriptive Record of the History, Religion, Literature, and Customs of the Jewish People from the Earliest Times to the Present Day. New York: Funk \& Wagnalls, vol. 11, p. 314.

Ehrlinger, Naphtali. 1947-2018. Kutim. In Talmudic Encyclopedia. Jerusalem: Talmudic Encyclopedia Institute, vol. 27, pp. 649-730. (In Hebrew)

Eisenstein, Judah David. 1915. Ozar Midrashim: Bet eked le-matayim midrashim ketanim va-agadot u-ma'asiyiot. New York: J. D. Eisenstein.

Eisenstein, Judah David. 1920. Ozar Perushim we-Ziyurim al Haggadah shel Pesah, A Compendium in Hebrew of Authoritative Commentaries and Original Illustrations. New York: J. D. Eisenstein.

Elbaum, Jacob. 1987. 'Sefer Ha-Aggadah' - A Prolegomenon. Jerusalem Studies in Hebrew Literature 10-11: 375-97. (In Hebrew).

Elbaum, Jacob. 2014. The Quiet Revolution: Louis Ginzberg's The Legends of the Jews and Jewish Anthological Literature. In Louis Ginzberg's Legends of the Jews: Ancient Jewish Folk Literature Reconsidered. Edited by Galit Hasan-Rokem and Ithamar Gruenwald. Detroit: Wayne State University Press, pp. 64-78.

Farber, Zev. 2016. Images of Joshua in the Bible and Its Reception. Berlin: De Gruyter.

Farissol, Abraham. 1524. Sefer Orhot 'Olam. Ferrara: n.p.

Fine, Gary A. 1987. Joseph Jacobs: A Sociological Folklorist. Folklore 98: 183-93. [CrossRef]

Fine, Steven. 2010. Art and Judaism in the Greco-Roman World: Toward a New Jewish Archaeology, rev. ed. Cambridge: Cambridge University Press.

Fine, Steven. 2020. The Treason of Yosa Meshita (Genesis Rabba 65:27): A Rabbinic Reflection on the Fate of the Temple Lampstand. In From Scrolls to Traditions: A Festschrift Honoring Lawrence H. Schiffman. Edited by Stuart S. Miller, Michael D. Swartz, Steven Fine, Naomi Grunhaus and Alex P. Jassen. Boston: Brill, pp. 254-75.

Fine, Steven. Forthcoming. How Much Christianity in Rabbinic Judaism? A Coda.

Flusser, David, ed. 1980. Sefer Yosippon: Yotse le'or sadur u-mugah al-pi kitve-yad be-livyat mavo, be'ûrim ve-hilufe girsa'ot. Jerusalem: Mossad Bialik.

Gaster, Moses. 1908a. Das Buch Josua in Hebräisch-Samaritanischer Rezension. Leipzig: Brockhaus.

Gaster, Moses. 1908b. My Reply. Journal of the Royal Asiatic Society, 1148-56. [CrossRef]

Gaster, Moses. 1925. The Samaritans, Their History, Doctrines and Literature. London: The British Academy. 
Ginzberg, Louis. 1900. Die Haggada bei Den Kirchenvätern und der apokryphischen Litteratur: Die Haggadah in Den Pseudo-Hieronymianishen "Questiones". Berlin: S. Calvary.

Ginzberg, Louis. 1909-1938. Legends of the Jews. Translated by Henrietta Szold, and Paul Radin. Philadelphia: Jewish Publication Society.

Ginzberg, Eli. 1966. Louis Ginzberg: Keeper of the Law. Philadelphia: Jewish Publication Society.

Golinkin, David. 2014. 'The Legends of the Jews' in the Eyes of Louis Ginzberg and in the Eyes of Others. In Louis Ginzberg's Legends of the Jews: Ancient Jewish Folk Literature Reconsidered. Edited by Galit Hasan-Rokem and Ithamar Gruenwald. Detroit: Wayne State University Press, pp. 17-33.

Gottheil, Richard, and M. Seligman. 1901-1906. The Samaritan Book of Joshua. In The Jewish Encyclopedia: A Descriptive Record of the History, Religion, Literature, and Customs of the Jewish People from the Earliest Times to the Present Day. New York: Funk \& Wagnalls, vol. 7, pp. 287-89.

Graetz, Heinrich. 1854-1855. Hagadische Elemente bei den Kirchenvätern. Monatsschrift für die Geschichte und Wissenschaft des Judentums 3: 311-18, 352-55, 381-87, 428-31, 4: 186-92.

Greenspahn, Frederick E. 2000. The Beginnings of Judaic Studies in American Universities. Modern Judaism-A Journal of Jewish Ideas and Experience 20: 209-25. [CrossRef]

Hacker, Joseph R. 2012. Readers and Printers of Sixteenth-Century Hebrew Books in the Ottoman Empire. Perspectives on the Hebrew Book: The Myron M. Weinstein Memorial Lectures at the Library of Congress. Edited by Peggy K. Pearlstein. Washington, DC: Library of Congress.

Hacker, Joseph R. 2017. The Rise of Ottoman Jewry (1400-1580). The Cambridge History of Judaism, vol. 7: The Early Modern Period, c.1500-c.1815. Edited by Jonathan Karp and Adam Sutcliffe. Cambridge: Cambridge University Press, pp. 77-112.

Hasan-Rokem, Galit. 2014. Ancient Jewish Folk Literature: The Legends of the Jews and Comparative Folklore Studies at the Beginning of the Twentieth Century. In Louis Ginzberg's Legends of the Jews: Ancient Jewish Folk Literature Reconsidered. Edited by Galit Hasan-Rokem and Ithamar Gruenwald. Detroit: Wayne State University Press, pp. 79-104.

Havrelock, Rachel. 2020. The Joshua Generation: Israeli Occupation and the Bible Princeton. Princeton: Princeton University Press.

Heinemann, Joseph. 1973. Anti-Samaritan Polemics in the Aggadah. World Congress of Jewish Studies 6: 57-69.

Heller, Bernhard. 1933-1934. Ginzberg's Legends of the Jews. Jewish Quarterly Review, New Series 24: 51-66, 165-90, 281-307, 393-418, 25: 29-52. [CrossRef]

Heller, Bernhard, and Moses Gaster. 1933. Samaritanisches. Monatsschrift für die Geschichte und Wissenschaft des Judenthums 77: 300-5.

Holtzman, Avner. 1995. Towards the Tear in the Heart: Micha Josef Berdyczewski- The Formative Years (1886-1902). Jerusalem: Bialik Institute. (In Hebrew)

Jacobs, Joseph. 1914. Legends of the Jews: Die Sagen der Juden by Micha Josef bin Gorion. Jewish Quarterly Review, New Series 4: 499-502. [CrossRef]

Juynboll, Theodoor G. J. 1848. Chronicon Samaritanum: Arabice Conscriptum, Cui Titulus Est Liber Josuae: Ex Unico Codice Scaligeri Nunc Primum Edidit, Latine Vertit, Annotatione Instruxit, Et Dissertationem De Codice, De Chronico, Et De Quaestionibus, Quae Hoc Libro Illustrantur. Lugduni Batavorum: S. \& J. Luchtmans.

Kelman, Baruch-Lev. Forthcoming. A Samaritan Torah Curtain in a Jewish Synagogue? A Responsum of Jacob b. David ibn Yahya 1622.

Keren, Michael, and Shlomit Keren. 2010. We Are Coming, Unafraid: The Jewish Legions and the Promised Land in the First World War. Lanham: Rowman \& Littlefield.

Kiel, Mark W. 1997. Sefer ha'aggadah: Creating a Classic Anthology for the People and by the People. Prooftexts 17: 177-97.

Kirchheim, Raphael. 1851. Karme Shomron: Petihah le-Masekhet Kutim. Frankfurt: I. Kaufmann.

Kopserlish, Abraham. 1669. Tzemah David. Germany (Cleves?), Handwritten Manuscript. JTS.469 [1669 MS 3543, SHF 1541:8]. New York: Jewish Theological Seminary.

Lequtei ha-Ma'asim ha-Nimtsaim be-Ven Sira. 1648. Verona: n.p.

Luncz, Abraham Moses. 1902. Das Buch Josua der Samaritaner in Hebräisch. Jerusalem: Jahrbuch zur Beförderung einer wissenschaftlich genauen Kenntniss des jetzigen und des alten Palästinas 6: 138-55.

Marchand, Suzanne L. 2013. German Orientalism in the Age of Empire: Religion, Race, and Scholarship. Cambridge: Cambridge University Press.

Mishor, Mordechay. 2000. “Tibat Marqe' y el midrás: Paralelos samaritanos-rabínicos,” ‘Ilu; revista de ciencias de las religiones. Madrid. Cuadernos 3: 111-26.

Montgomery, James Alan. 1907. The Samaritans: The Earliest Jewish Sect. Philadelphia: J.C. Winston Company.

Neubauer, Adolf. 1909. Helek ha-Aharon shel ha-Ma'amar ha-Sheshi shel Sefer Yuhasin le-R' Avraham Zekhut. In Festschrift zum achtzigsten geburtstage Moritz Steinschneider's. Leipzig: O. Harrassowitz, pp. 209-19.

Newman, Hillel I. 2010. Louis Ginzberg, 'The Legends of the Jews', and the Church Fathers. In Die Entdeckung des Christentums in der Wissenschaft des Judentums. Edited by Görge K. Hasselhoff. Berlin: De Gruyter, pp. 183-94, rpt. Louis Ginzberg's Legends of 
the Jews: Ancient Jewish Folk Literature Reconsidered. eds. Galit Hasan-Rokem, and Ithamar Gruenwald. Detroit: Wayne State University Press, pp. 34-48.

Niessen, Friedrich. 2000. Eine samaritanische Version des Buches Yehošua' und die Šobak-Erzählung: Die samaritanische Chronik Nr. II, Handschrift 2: JR (G) 1168= Ryl. Sam. MS 259, Folio 8b-53a. Hildesheim: Georg Olms Verlag.

Niessen, Friedrich. 2002. A Judaeo-Arabic Fragment of a Samaritan Chronicle from the Cairo Geniza. Journal of Semitic Studies 47: 215-36. [CrossRef]

Oser, Asher C. 2020. When an American Jew Produced: Judah David Eisenstein and the First Hebrew Encyclopedia. Ph.D. dissertation, New York, NY, USA.

Patterson, John Henry. 1922. With the Judxans in the Palestine Campaign. London: Hutchinson \& Co.

Pummer, Reinhard. 1993. Samaritan Marriage Contracts and Deeds of Divorce: Volume I. Wiesbaden: O. Harrassowitz.

Pummer, Reinhard. 1998. The Samaritans in Egypt. In Études sémitiques et samaritaines offertes à Jean Margin. Edited by ChristianBernard Amphoux, Albert Frey and Ursula Schattner-Rieser. Lausanne: Éditions du Zèbre, pp. 213-32.

Pummer, Reinhard. 2016. The Samaritans: A Profile. Grand Rapids: William B. Eerdmans.

Ruderman, David B. 1981. The World of a Renaissance Jew: The Life and Thought of Abraham ben Mordecai Farissol. Cincinnati: Hebrew Union College Press.

Runia, David T. 1984. History of Philosophy in the Grand Manner: The Achievement of H.A. Wolfson. Philosophia Reformata 49: 112-33. [CrossRef]

Schatz, Andrea. 2019. A Tradition in the Plural: Reframing Sefer Yosippon for Modern Times. In Josephus in Modern Jewish Culture. Edited by Andrea Schatz. Boston: Brill, pp. 62-84.

Schatz, Andrea, and Pavel Sládek. Forthcoming. The Editor's Place: Samuel Boehm and the Transfer of Italian Print Culture to Krakow.

Schick, Shana Strauch, and Steven Fine. Forthcoming. "'Do You Have an Onion?' Samaritans and Rabbis in the Galilee during Late Antiquity," The Samaritans: A Biblical People. Edited by Steven Fine. Boston: Brill, New York: Yeshiva University Press.

Schorsch, Rebecca. 2003. The Making of a Legend: Louis Ginzberg's “Legends of the Jews". Ph.D. dissertation, University of Chicago, Chicago, IL, USA.

Schorsch, Rebecca. 2014. Introduction: The Past in the Service of the Present-Rabbinicizing Folklore or Folklorizing the Rabbis? In Louis Ginzberg's Legends of the Jews: Ancient Jewish Folk Literature Reconsidered. Edited by Galit Hasan-Rokem and Ithamar Gruenwald. Detroit: Wayne State University Press, pp. 1-16.

Schwartz, Shuly Rubin. 1991. The Emergence of Jewish Scholarship in America: The Publication of the Jewish Encyclopedia. Cincinnati: Hebrew Union College Press.

Schwartz, Yitzchak. Forthcoming. Samaritans on the American Protestant Mind: William Barton, Edward Warren and the American Samaritan Committee. In The Samaritans: A Biblical People. Edited by Steven Fine. Boston: Brill, New York: Yeshiva University Press.

Sefer ha-Yashar. 1625. Venice: n.p.

Sefer Tam ve-Yashar. 1674. Frankfurt am Main: n.p.

Sefer Tam ve-Yashar. 1768. Fürth: Hayyim b. Hirsh.

Sefer Tam ve-Yashar. 1783. Sulzbach: Zekl b. Aharon.

Shinan, Avigdor. 1987. The World of the Aggadic Literature. Tel Aviv: Ministry of Defense. (In Hebrew)

Shpigel, Gideon. 1998. The Jewess of Constantinople: The Story of Esther Kira (1539-1592). Mahut 20: 55-79. (In Hebrew).

Silman, M. M. 1900. Ha-Shomronim. In Aviv: Osef Ma'amarim, Shirim u-Sippurim la-Migra Benei ha-Ne'orim. Edited by Yehoshua H. Ravnitsky. Warsaw: Sholdberg, pp. 53-71.

Sorkin, David. 2019. Jewish Emancipation: A History across Five Centuries. Princeton: Princeton University Press.

Paul Stenhouse, trans. 1985, The Kitāb al-Tarīkh of Abu 'l-Fath. Sydney: University of Sydney.

Sulzberger, Mayer. 1917. Joseph Jacobs. The American Jewish Year Book 18: 68-75.

Tam, Jacob b. David ibn Yahya. 1622. Sefer Tamat Yesharim. Venice: n.p.

Turniansky, Chava. 1985. The First Yiddish Translations of 'Sefer Hayashar'. Tarbiz 54: 567-620. (In Hebrew).

Yalqut Reuveni, ed. 1700. Reuben ben Hoshke Sofer, 2nd ed. Amsterdam: A. Atias.

Yellin, David. 1907-1908. ha-Shomronim: H-eker Divre Yemehem, Sefatam, Sifrutam, Emunatam, Minhagehem u-Matsavam be-Yamenu Eleh. Jerusalem: Levi.

Zacuto, Abraham. 1566. Sefer Yuhasin. Edited by Samuel Sulam. Istanbul: n.p.

Zacuto, Abraham. 1580. Sefer Yuhasin. Cracow: Isaac Prostitz.

Zacuto, Abraham. 1963. Sefer Yuhasin ha-Shalem, 3rd ed. Edited by Herschel Filipowski and Avraham Høayim Fraimann. Jerusalem: Hevra Meorerei Yeshanim.

Zipperstein, Steven J. 2018. Pogrom: Kishinev and the Tilt of History. New York: Liveright. 